\title{
形態制御トラス構造のアクチュエータ配置理論 ACTUATOR ARRANGEMENT THEORY FOR SHAPE CONTROL OF TRUSS STRUCTURE
}

\author{
金井頼 利*，半谷裕彦** \\ Yoritoshi KANAI and Yasuhiko HANGAI
}

\begin{abstract}
For static and dynamic systems, shape control structure can be defined as shape of structure is controlled by actuators, etc., in order to satisfy the prescribed shape condition. The paper presents an arrangement theory of actuator. In the first part of the paper, the load-displacement relation with the constraint condition of displacement is theoretically analyzed by using the Bott.Duffin inverse and the generalized inverse to derive the actuator forces. In the second part, necessary and sufficient condition for the existence of actuator arrangement is formmulated. In the third part, the arrangement theory of actuator is formulated by the coefficient matrix of the reaction-axial relation. In the final part, a numerical example is shown in order to examine the validity of the present method.
\end{abstract}

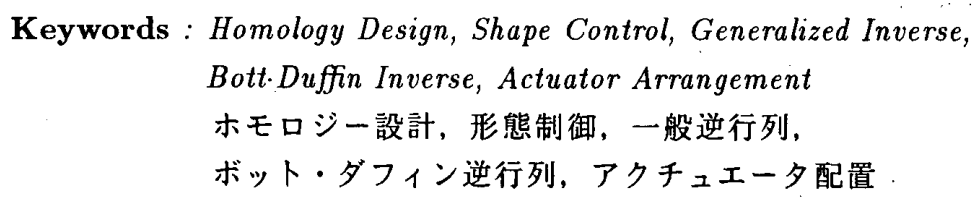

\section{1. 研究目的}

構造物や機器を設計する際における最適設計問題のひ とつに形態設計があり、多くの研究がなされている1) 5)。 形態解析を行う場合には目標となる量、あるいは目標と なる形態が必要である。既往の研究の多くは、最小重量 や最大剛性、あるいは一様応力や一様ひずみエネルギー 密度等を目標としている。例えば岩蛋等 ${ }^{6)}$ は、秉軟構造 物の断面積の変化率およびセンサーとアクチュエータの 位置を設計変数として、構造・制御系の同時最適設計法 を開発している。最近では、構造物の持つ機能を目標と する形隼解析も試みられている7)。著者は文献 ${ }^{8)}$ におい て、変形モードを目標とする形態解析法を提案し、さらに その構造力学的な特徵を調查しだ)。これらの論文で扱っ た変形モード指定の形㦔解析では「指定された荷重下に おいて構造、あるいは構造の一部が変形前・後において 指定した形状と同一となるように構造形態を決定するこ と」を目標としている。このような変形はホモロガス変
形と呼ばれ、ホモロガス変形を目標とする形態設計はホ モロジ一設計と名付けられている ${ }^{10,11) 。 ~}$

本論文では、形態自身を環境条件に応じて制御する「 形態制御構造」を扱う。特にここでは、アクチュエータを 組み込んだ構造システムを形態制御椣造として取り上げ、 ホモロガス変形を満足する形態制御法を述へる。形態制 御をアクチュエータによりおこなう場合、指定した形状 (ホモロガス変形) を保持するためには適当なアクチュエ 一夕の配置が必要となる。本論文では、トラス構造に対 して指定した形態制御を可能とするアクチュエータの配 置を理論的に求める方法を提示する。

\section{2. 形態制御搆造の課題}

簡単な例を用いながら、本研究で扱う形態制御構造の 研究課題を整理しておく。形態制御をおこなうトラス樓 造を「基本トラス」と名付ける。この基本トラスに指定 した荷重 $f$ を作用させる(図 1)。この基本トラスの満足

本論文の一部は, 1994年度第18回構造工学における数值解析法シンポジウム ${ }^{13)}$ で発表している。

* 職業能力開発大学校 講師・工修 ～Lecturer, Polytechnic University, M. Eng.

** 東京大学生産技術研究所 教授 - 工博 · Prof., Institute of Industrial Science, University of Tokyo, Dr. Eng. 


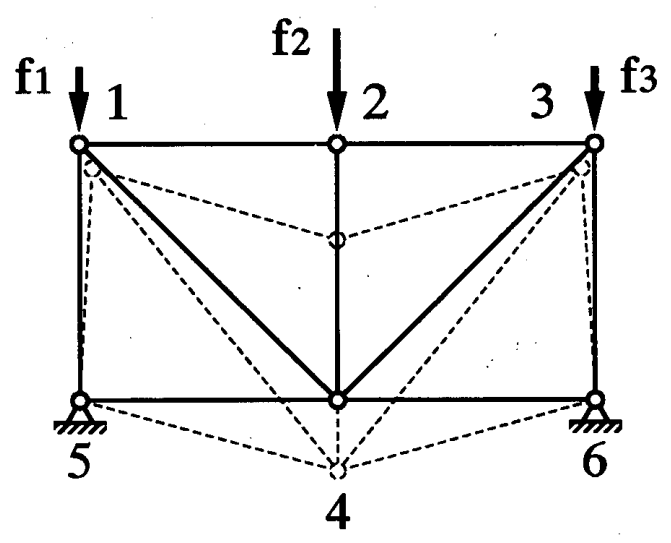

図 1：基本トラス

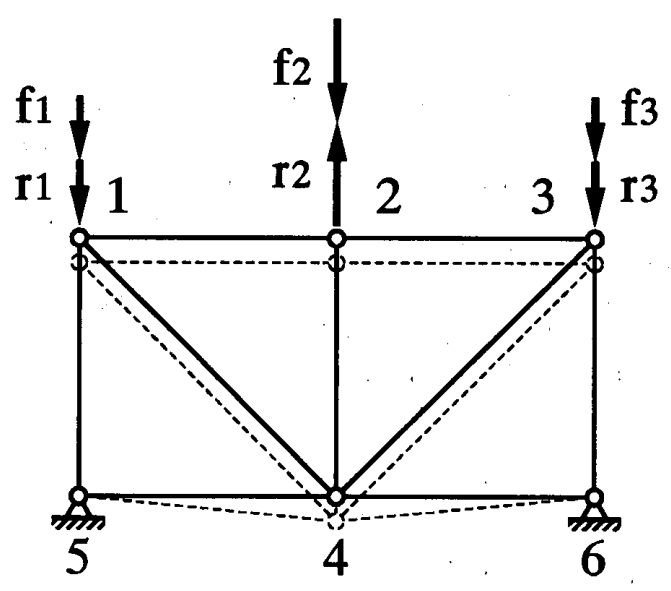

図 2: 節点力 $\boldsymbol{r}$ とホモロガス変形

すべきホモロガス変形を指定する。例えば、图1のトラ ス構造で、節点 $1,2,3$ の鉛直方向变位を同一とする条件を 指定する。図 1 の点線で示すように、制御を行わない基 本トラスではこの条件を満足しない。そこで、ホモロガ ス変形を満足するように外部から節点力 $\boldsymbol{r}$ を作用する。 この $r$ を作用すると変位は図 2 となり、ホモロガス変形 を満足する。次に節点力 $\boldsymbol{r}$ を内部に組み込んだアクチュ エータで生じさせることを考える。道当に配置したアク チュエターによる節点力を $\boldsymbol{R}$ とするとき、 $\boldsymbol{r}=\boldsymbol{R}$ となる アクチュエータの配置を決定する(図 3)。アクチュエータ を配置した節点間のトラス部材を消去したトラス構造を 「消去卜ラス」と名付ける(図 4)。消去卜ラスにアクチュ エータを組み込んだトラス構造を「制御トラス」と名付 ける(図 5)。

以上の内容を理論的に解析するためには次の研究課題 を解決する必要がある。

課題 1 ： ホモロガス変形を満足するための節点力 $\boldsymbol{r} の$ 評価

課題 $2 ： r=R$ となるアクチュエータの配置。

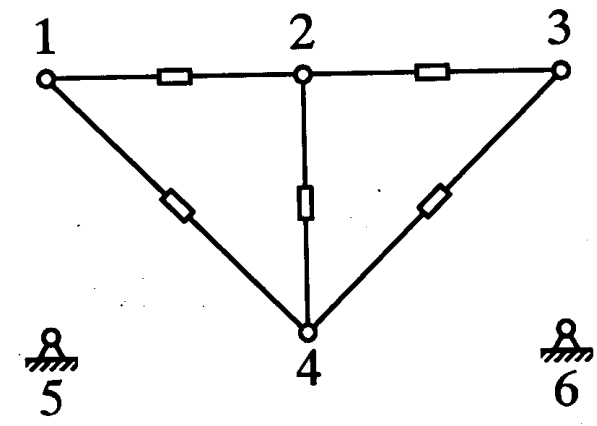

図 3：アクチュエータ配置

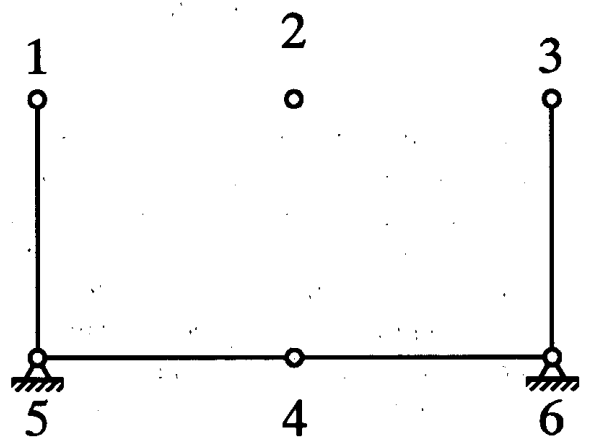

図 4: 消去トラス

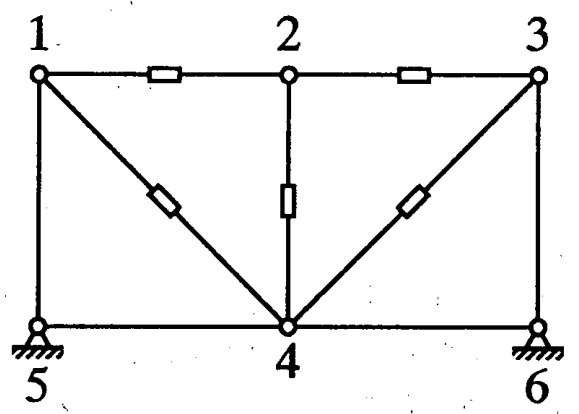

図 5: 制御トラス

課題 3 : 制御トラスの変位 $\boldsymbol{u}$ とアクチュエータカ $\boldsymbol{R} の$ 評価

\section{3. 基礎方程式}

次式で与えられる変位に関する制約条件付きの荷重－ 変位関係式を考える。

$$
\begin{aligned}
& \boldsymbol{K d}=\boldsymbol{f} \\
& \boldsymbol{A d}=\boldsymbol{g}
\end{aligned}
$$

ここに、 $\boldsymbol{K}:(n \times n)$ 型対称剛性マトリックス、 $\boldsymbol{d}: n$ 次変位ベクトル、 $\boldsymbol{f}: \boldsymbol{n}$ 次荷重ベクトル、A $:(m \times n)$ 型制約条件マトリックス、 $g: n$ 次制䄪ベクトル、 $n:$ 自由度数、 $m$ ：制約条件数 $(m<n$ とする)でおる。 制約条件をすへで独立であるとすると 


$$
\operatorname{rank}(\boldsymbol{A})=m
$$

$\boldsymbol{A} \cdot$ の行数とランクが一致しているので、A $\boldsymbol{A}$ はフルラン クであり、次式が成立する ${ }^{12)}$ 。

$$
\begin{gathered}
A^{+}=A^{T}\left(A A^{T}\right)^{-1} \\
A A^{+}=I_{m}
\end{gathered}
$$

ここに、 $\boldsymbol{A}^{+}: \boldsymbol{A}$ の Moore-Penrose 一般逆行列、 $\mathrm{T}:$ 転 置記号、 $I_{m}: m$ 次単位行列である。式 (5) は成立する が、一般には $A^{+} A=I_{n}$ は成立しない。

式 (1), (2) は次式で与えられる変位に関する制約条件 付きのポテンシャル・エネルギー関数の最小化問題と等 価である。

$$
\begin{gathered}
\Pi=\frac{1}{2} d^{T} K d-f^{T} d \\
A d=g
\end{gathered}
$$

そこで、上式を Lagrange 乗数ベクトル $\lambda$ を導入し、 $d$ と入の $(n+m)$ 個を未知量とする制䄪条件無しの最小 化問題に変換する。その場合のポテンシャル・エネルギ 一関数は次式となる。

$$
\Pi_{k}=\frac{1}{2} d^{T} K d-f^{T} d+\lambda^{T}(A d-g)
$$

$d$ と入の各成分で偏微分し、零とおくことにより、 $d$ と $\lambda$ を末知量とする $(n+m)$ 個の連立方程式が得られ る。つまり、

$$
\begin{gathered}
K d-f+A^{T} \lambda=0 \\
A d-g=0
\end{gathered}
$$

上式の誘導において $K^{T}=K$ を利用している。ここで

$$
\boldsymbol{r}=\boldsymbol{A}^{T} \lambda
$$

と置くと、式 (9) は次式となる。

$$
K d+r=f
$$

以上によって、式 (1)，(2) で与えられる制約条件付きの 問題は、式 (12), (10) で与えられる $d$ とを末知量とす る連立方程式の解析に㷌着された。式 (5) より $\boldsymbol{A A}^{+}=$ $I_{m}$ が成立しているから、 $\left(A^{+}\right)^{T} A^{T}=I_{m}$ となり、この 式を用いる事により式 (11) は次式となる。

$$
\lambda=\left(A^{+}\right)^{T} r
$$

上式は $\boldsymbol{r}$ が得られれば $\boldsymbol{\lambda}$ あ計算できることを示してい る。ここで、 $n$ 次ベクトルu導入し、 $d$ を次式で $u$ に䞏換する。

あるいは、

$$
u=d-A^{+} g
$$

$$
d=u+A^{+} g
$$

上式を式 (12), (10) に代入すると

$$
\begin{gathered}
K u+r=f-K A^{+} g \\
A u=0
\end{gathered}
$$

ここで

$$
\boldsymbol{h}=\boldsymbol{f}-\boldsymbol{K} \boldsymbol{A}^{+} \boldsymbol{g}
$$

と䈯くと基礎方程式は次式となる。

$$
\begin{gathered}
K u+r=h \\
A u=0
\end{gathered}
$$

式（19）においてr $\boldsymbol{r}$ は荷重の単位を持ち、反力を意味し ている 12)。

\section{Bott・Duffin 逆行列による解析 (绉題 1)}

最初に $\boldsymbol{u}$ と $\boldsymbol{r}$ の直交性を示す。式 (11)，(17）を用い ると

$$
u^{T} r=u^{T} A^{T} \lambda=(A u)^{T} \lambda=0
$$

$L$ を $n$ 次元空間内の部分空間とし、 $L^{\perp}$ を $n$ 次元空間 内の $L$ に対する直交補空間とする。式 (21) より $u$ と は直交しているから

$$
\boldsymbol{u} \in L, \quad \boldsymbol{r} \in L^{\perp}
$$

となる。そこで、 $\boldsymbol{P}_{L}: L$ 上への正射影マトリックス、 $\boldsymbol{P}_{L^{\perp}}: L^{\perp}$ 上への正射影マトリックス、a: $n$ 次元空間 内のベクトルとすると次式が成立している。

$$
\begin{gathered}
u=P_{L} a, \quad r=P_{L^{\perp} a} \\
P_{L}+P_{L^{\perp}}=I_{n}
\end{gathered}
$$

式 (23) を式 (19) に代入すると

$$
\left[\boldsymbol{K} \boldsymbol{P}_{L}+\boldsymbol{P}_{L \perp}\right] \boldsymbol{a}=\boldsymbol{h}
$$

上式の係数マトリックスは $n$ 次正方マトリックスであ り、非特異の場合（安定構造の場合には成立する）、

$$
a=\left[K P_{L}+P_{L \perp}\right]^{-1} h
$$

上式を式 (23) に代入すると

$$
\begin{gathered}
\boldsymbol{u}=\boldsymbol{P}_{L}\left[\boldsymbol{K} \boldsymbol{P}_{L}+\boldsymbol{P}_{L^{\perp}}\right]^{-1} \boldsymbol{h} \\
\boldsymbol{r}=\boldsymbol{P}_{L^{\perp}}\left[\boldsymbol{K} \boldsymbol{P}_{L}+\boldsymbol{P}_{L^{\perp}}\right]^{-1} \boldsymbol{h}
\end{gathered}
$$

式 (27) で

$$
K_{(L)}^{(-1)}=P_{L}\left[K P_{L}+P_{L^{\perp}}\right]^{-1}
$$

と置くと、 $\boldsymbol{K}_{(L)}^{(-1)}$ は $\boldsymbol{K}$ の Bott・Duffin 逆行列と呼ばれ ている。 $\boldsymbol{u}$ を式 (15) に代入することにより、変位制䄪 を持つ粠造物の変位は、

となる。

$$
d=K_{(L)}^{(-1)} h+A^{+} g
$$

以上より、式 (1), (2) で与えられる問題の解析は $P_{L}$ と $P_{L \perp}$ の作成問題に㷌着された。 $P_{L}$ 及び $P_{L \perp}$ の自動化作 成法については、文献 [12] を参照して戴きたい。式 (28) が課題 1 に対する答となる。

\section{5. 制御力 $\boldsymbol{R}$}

図 6 に示すように、デカルト座標 $(0-x y z)$ を座標系 として採用し、節点 $i$ と節点 $j$ を結ぶ直線のトラス部材 を $a(a=1 \sim e, e:$ 部材数 $)$ とする。節点座標值べク トルと方向余弦ベクトルを次式とする。

$$
\boldsymbol{x}_{i}=\left[\begin{array}{c}
x_{i} \\
y_{i} \\
z_{i}
\end{array}\right], \quad \boldsymbol{x}_{j}=\left[\begin{array}{l}
x_{j} \\
y_{j} \\
z_{j}
\end{array}\right], \quad \boldsymbol{\lambda}_{a}=\left[\begin{array}{l}
\lambda \\
\mu \\
\nu
\end{array}\right]_{a}
$$




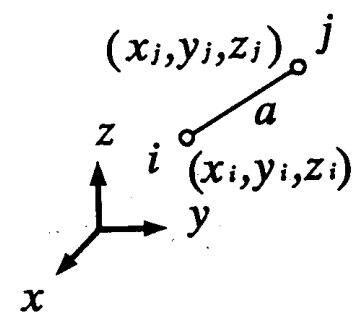

図 6：節点座標

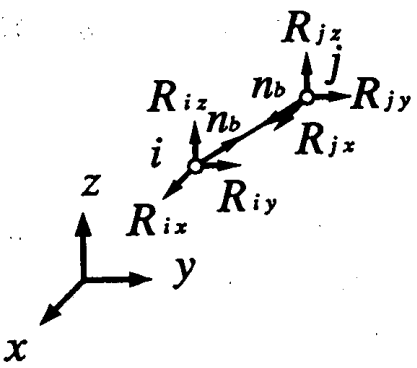

図 7:アクチュエータ力 と節点力
部材長を $l_{a}$ とすれば

$$
l_{a}=\left[\left(x_{j}-x_{i}\right)^{T}\left(x_{j}-x_{i}\right)\right]^{\frac{1}{2}}
$$

上式を用いると方向余弦べクトルは次式となる。

$$
\lambda_{a}=\frac{1}{l_{a}}\left(x_{j}-x_{i}\right)
$$

次に、アクチュエータを考える。图 7 に示すように節 点 $i 、 j$ を結ふアクチュエータを $b(b=1 \sim k, k:$ ア クチュエータ数) とする。アクチュエータbに作用してい る軸力を $n_{b}$ とし、 $n_{b}$ に制り合っている節点力を節点

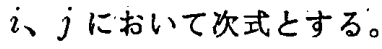

$$
\boldsymbol{R}_{i b}=\left[\begin{array}{c}
\boldsymbol{R}_{i x} \\
\boldsymbol{R}_{i y} \\
\boldsymbol{R}_{i z}
\end{array}\right]_{b}, \quad \boldsymbol{R}_{j b}=\left[\begin{array}{l}
\boldsymbol{R}_{j x} \\
\boldsymbol{R}_{j y} \\
\boldsymbol{R}_{j z}
\end{array}\right]_{b}
$$

このとき、アクチュエータ $b$ の釣合式は、

$$
\left[\begin{array}{r}
-\boldsymbol{\lambda}_{a} \\
\boldsymbol{\lambda}_{a}
\end{array}\right] n_{b}=\left[\begin{array}{l}
\boldsymbol{R}_{\boldsymbol{i}} \\
\boldsymbol{R}_{j}
\end{array}\right]_{b}
$$

上式を全アクチュエータについてまとめると

$$
B \dot{n}=R
$$

\section{6. アクチュエータ配置 (課題 2)}

式 (2) の制約条件は全て独立とする。つまり、

$$
\operatorname{rank}(\boldsymbol{A})=m
$$

上式より式 (2) の独立な列ベクトルは $m$ 個である。 $k$ 個のアクチェエータを式 (36) の係数マトリックスのラン クが $k$ となるように配置する。つまり

$$
\operatorname{rank}(\boldsymbol{B})=k
$$

$k$ 個のアクチュエータが指定した形状を保つに必要な節 点力を確保するには $\boldsymbol{R}=\boldsymbol{r}$ が成立すればよい。つまり

$$
\boldsymbol{B} n=r
$$

上式を $n$ を末知量とする連立方程式と考え、解を持つ 条件式を作ると福)

$$
\left[I-B B^{+}\right] r=0
$$

ここで上式を満足するアクチュエータの個数と配置を求
めれば課題 1は解決されることになる。

式 (39) の直接的解法として、本論文では節点力 $r$ を 基本卜ラスに作用し、軸力の生した部材をアクチュエー 夕とする方法を採用する。図 3 は $\boldsymbol{r}$ を作用したとき、軸 力が零でない部材を、図 4 は軸力が零となっている部材 に対応している。

\section{7. 制御トラスの解析 (課題 3)}

消去トラスの剛性マトリックスを $\boldsymbol{K}_{d}$ とし、アクチュ エータによる制御力を $\boldsymbol{R}$ とする。このとき、次の验合方 程式と制約条件式を得る。

$$
\begin{gathered}
K_{d} d+R=f \\
A d=g
\end{gathered}
$$

3 章でおこなったと同様の方法によって、式 (42) の制御 ベクトル $\boldsymbol{g}$ の消去手続きを行う。

$$
u=d-A^{+} g \text { 叉は } d=u+A^{+} g
$$

と置くと

$$
\begin{aligned}
\boldsymbol{K}_{d} \boldsymbol{u}+\boldsymbol{r} & =\boldsymbol{h} \\
\boldsymbol{A} \boldsymbol{u} & =\mathbf{0}
\end{aligned}
$$

ただし、 $h=f-K_{d} A^{+} g$ である。ここで $R$ と 交性を示す。

$$
\begin{aligned}
\boldsymbol{R}^{T} u & =r^{T} u=\left(A^{T} \lambda\right)^{T} u=\lambda^{T} A u=0 \\
& =(B n)^{T} u=n^{T} B^{T} u=0
\end{aligned}
$$

即ち、Rとuは直交していて、かつ制䄪条件 $\boldsymbol{A u}=\mathbf{u}$ と $B^{T} u=0$ は等価である。従って次の基礎方程式を得る。

$$
\begin{array}{r}
\boldsymbol{K}_{d} \boldsymbol{u}+\boldsymbol{R}=\boldsymbol{h} \\
\boldsymbol{B}^{T} \boldsymbol{u}=\mathbf{0}
\end{array}
$$

$\boldsymbol{R}$ と $\boldsymbol{u}$ は、3 章と同様の方法により下式を得る。

$$
\begin{aligned}
\boldsymbol{R} & =\boldsymbol{P}_{L^{\perp}}\left[\boldsymbol{K}_{d} \boldsymbol{P}_{L}+\boldsymbol{P}_{L^{\perp}}\right]^{-1} \boldsymbol{h} \\
\boldsymbol{u} & =\boldsymbol{P}_{L}\left[\boldsymbol{K}_{d} \boldsymbol{P}_{L}+\boldsymbol{P}_{L^{\perp}}\right]^{-1} \boldsymbol{h}
\end{aligned}
$$

従って $\boldsymbol{d}, \boldsymbol{n}$ は次式となる。

$$
\begin{aligned}
\boldsymbol{d} & =\boldsymbol{P}_{L}\left[\boldsymbol{K}_{d} \boldsymbol{P}_{L}+\boldsymbol{P}_{L^{\perp}}\right]^{-1} \boldsymbol{h}+\boldsymbol{A}^{+} \boldsymbol{g} \\
\boldsymbol{n} & =\boldsymbol{B}^{+} \boldsymbol{R} \\
& =\boldsymbol{B}^{+} \boldsymbol{P}_{L^{\perp}}\left[\boldsymbol{K}_{d} \boldsymbol{P}_{L}+\boldsymbol{P}_{L^{\perp}}\right]^{-1} \boldsymbol{h}
\end{aligned}
$$

\section{8.アクチュエータ配置の具体例}

図 8 に示す 2 個のトラスを用いてアクチュエータ配置 の具体例を述べる。図 8 に示すトラスにおいて、ヤング 率: $2.1 \times 10^{8} \mathrm{kPa}$ ，断面皘： $10 \mathrm{~cm}^{2}$ とする。また制 約条件として、上部節点の鉊直方向変位を同一とする（ 節点 $1,2,3$ は常に同一直線上にある)。このとき、 $d y_{1}=d y_{2}=d y_{3}$ であるから、式(2) の係数マトリック ス $\boldsymbol{A}$ 及び制約べクトル $\boldsymbol{g}$ は次式となる。 


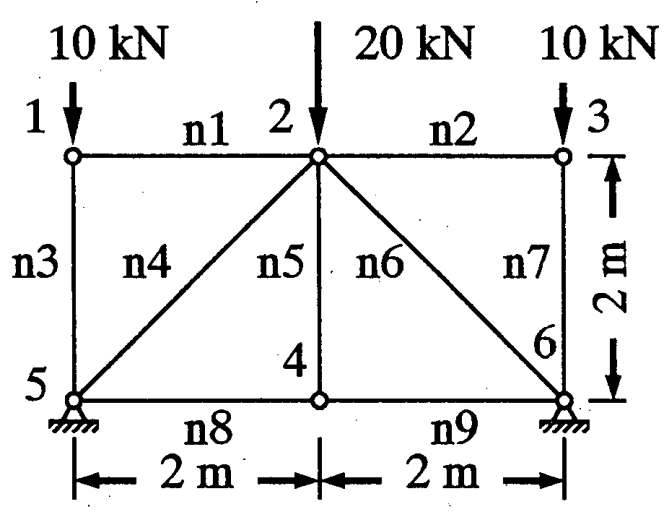

(a) Type-1

図 8：基本卜ラス

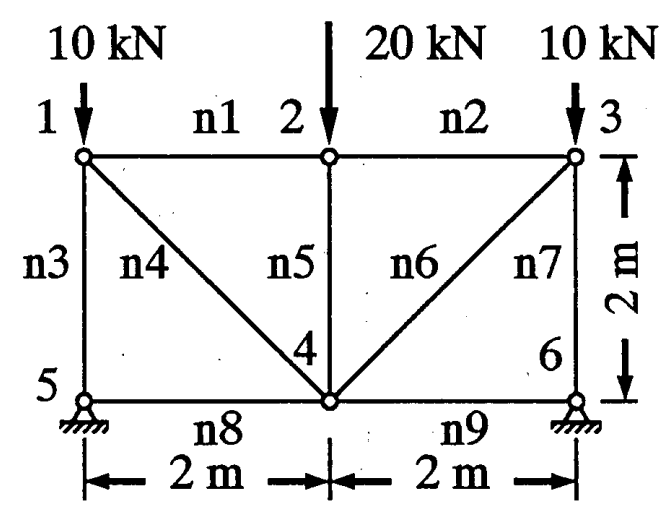

(b) Type-2

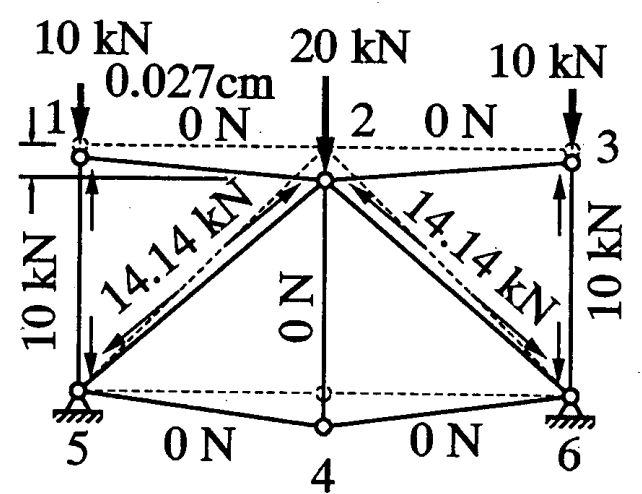

(a) Type-1

図 9：変形図 (非制御)

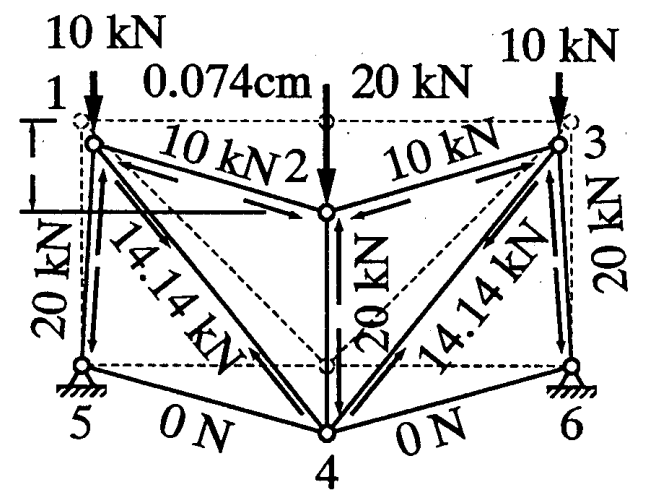

(b) Type-2

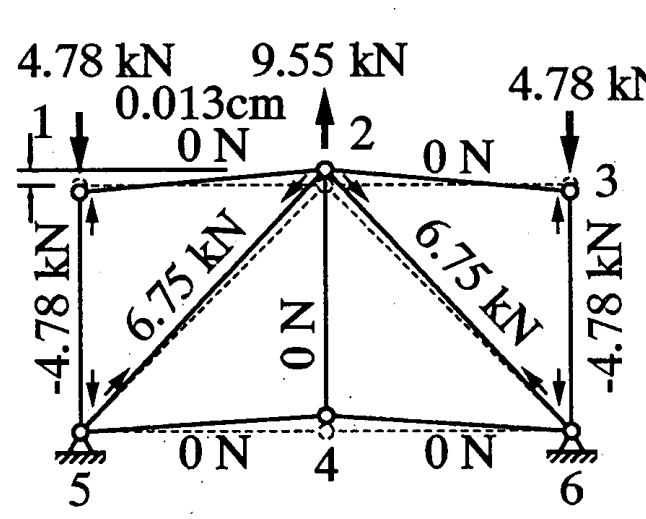

(a) Type-1

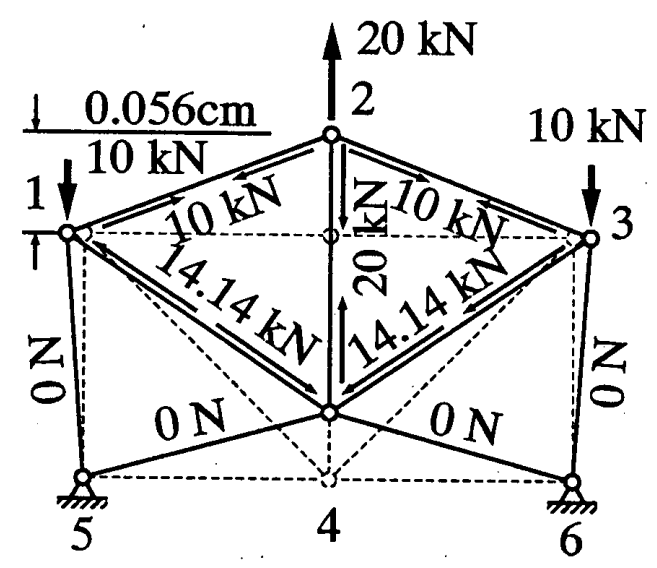

(b) Type-2

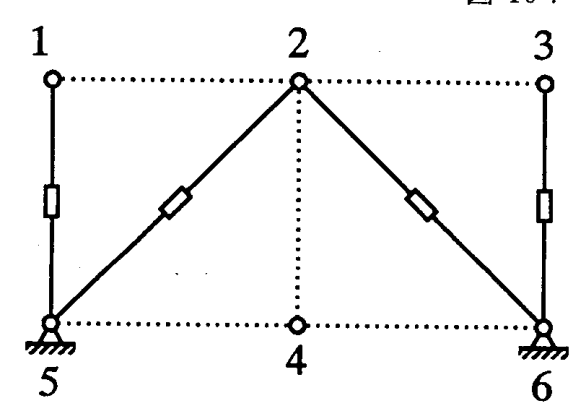

(a) Type-1

図 10 ：制御力 $\boldsymbol{r}$ による変形、応力図

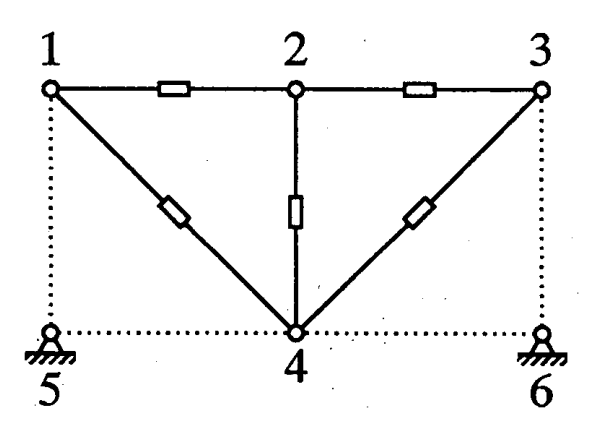

(b) Type-2

図 11：アクチュエータ配置図 


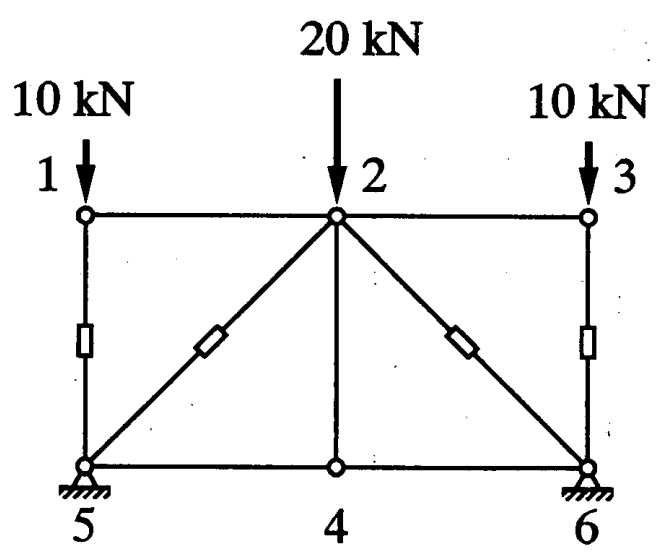

(a) Type-1

図 12 : 制御トラスの変形図

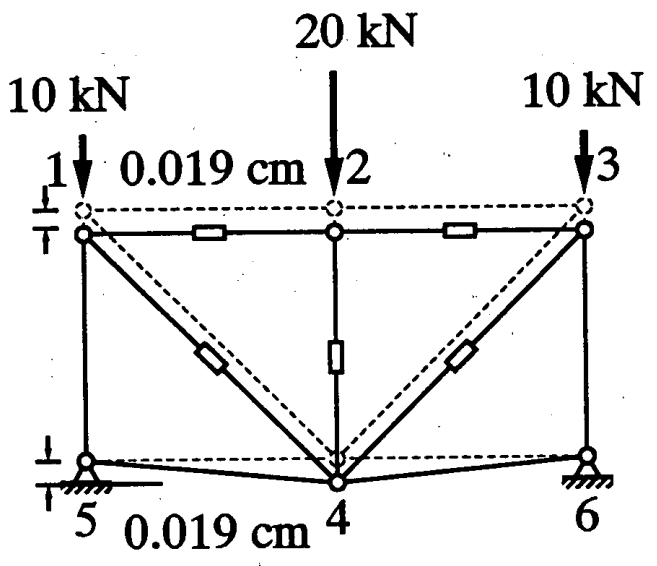

(b) Type-2

\section{$20 \mathrm{kN}$}

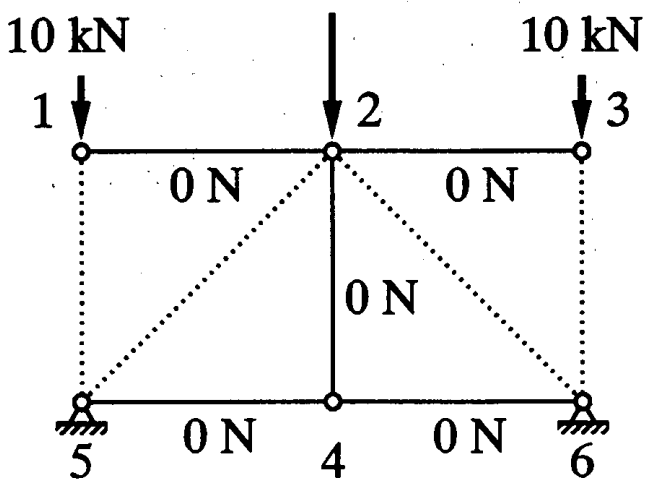

(a) Type-1

図 13：消去卜ラスの部材応力図

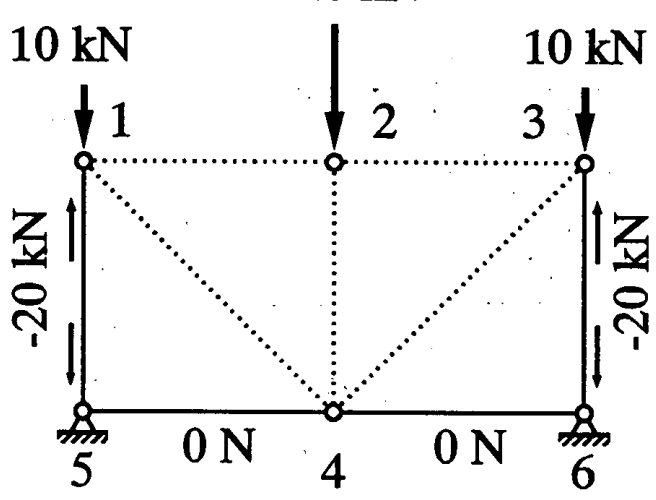

(b) Type-2

\section{$20 \mathrm{kN}$}

\section{$20 \mathrm{kN}$}

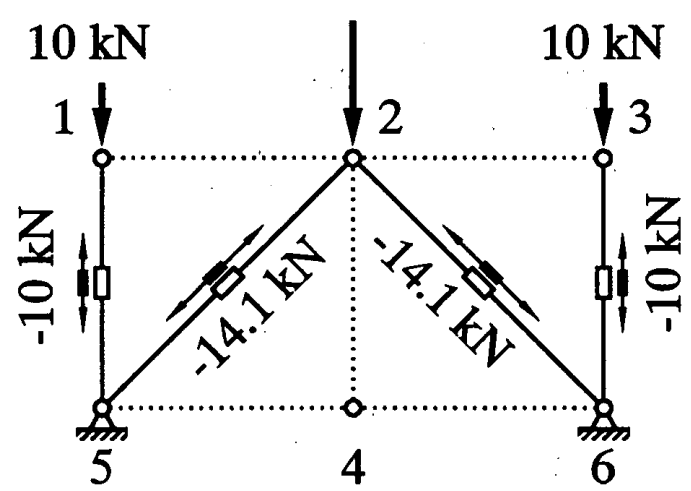

(a) Type-1

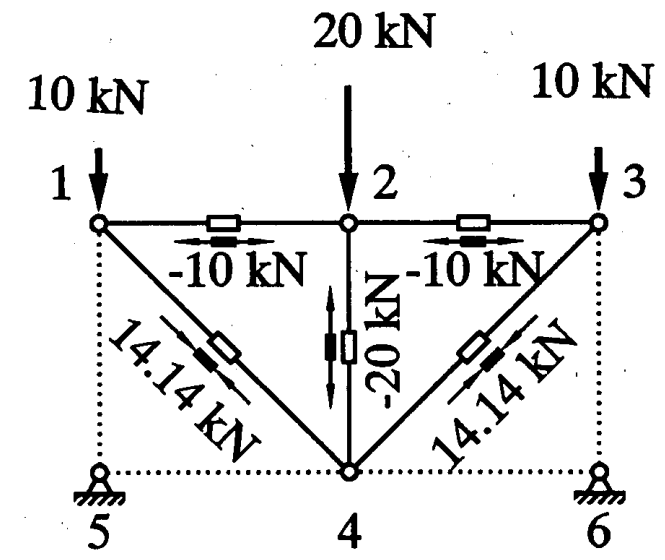

図 14：アクチュエータ力

(b) Type-2

$$
\boldsymbol{A}=\left[\begin{array}{cccccccc}
0 & 1 & 0 & -1 & 0 & 0 & 0 & 0 \\
0 & 0 & 0 & 1 & 0 & -1 & 0 & 0
\end{array}\right], \quad \boldsymbol{g}=\left[\begin{array}{l}
0 \\
0
\end{array}\right]
$$

荷重として、図 8 に示す荷重を作用する。図 9 に制御し ない場合の変位モードを示す。この場合には節点 1,2 , 3 は制䄪条件を満足していないことがわかる。式 (28) を用いて $\boldsymbol{r}$ を求めると(単位: $k N)$ 、
Type-1

$$
r=\left[\begin{array}{llllllll}
0 & 4.78 & 0 & -9.55 & 0 & 4.78 & 0 & 0
\end{array}\right]^{T}
$$

Type-2

$$
r=\left[\begin{array}{llllllll}
0 & 10 & 0 & -20 & 0 & 10 & 0 & 0
\end{array}\right]^{T}
$$


次きに $r$ を基本トラスに作用させて、部材力を求める(図 10)。

Type-1

$\boldsymbol{n}=\left[\begin{array}{ccccccccc}\mathrm{n} 1 \mathrm{n} 2 & \mathrm{n} 3 & \mathrm{n} 4 & \mathrm{n} 5 & \mathrm{n} 6 & \mathrm{n} 7 & \mathrm{n} 8 & \mathrm{n} 9 \\ 0 & 0 & 4.78 & -6.75 & 0 & -6.75 & 4.78 & 0 & 0\end{array}\right]^{T}(58)$

Type-2

$\boldsymbol{n}=\left[\begin{array}{rrlcccccc}\mathrm{n} 1 & \mathrm{n} 2 & \mathrm{n} 3 & \mathrm{n} 4 & \mathrm{n} 5 & \mathrm{n} 6 & \mathrm{n} 7 & \mathrm{n} 8 & \mathrm{n} 9 \\ -10 & -10 & 0 & 10 \sqrt{2} & -20 & 10 \sqrt{2} & 0 & 0 & 0\end{array}\right]^{T}(59)$

上式で零でない部材をアクチュエータで置き換えればよ いことになるから、図11のアクチュエータ配置が得ら れる。Type-1 のアクチュエータは、全て支持節点に結 合されている (外部制御)。一方 Type-2 では、アクチュ エータは全て自由節点間に配置されている (内部制御)。 このときの変位とアクチュエータ力を図 12 に示す。節 点 $1,2,3$ は、同一の鉛直変位となっていることがわかる。 また図 13,14 には部材応力、アクチュエータ力を示す。

\section{9. 制御方法}

アクチュエータの伸び剛性をトラス部材の伸び剛性よ りも大きいものとする。式 (52) から得られた変位を用い て、アクチュエータの制御長さを求める。アクチュエータ を変位制御し、この制御長さを保持することにより形態 制御が可能となる。

\section{0. 結論}

本論文はアクチュエータを棈造に組み込むことによって 構造の形状を制御する形態制御構造を扱っている。形態 制御棈造では、指定した形状を保持するためのアクチュ エータ配置が設計時の課題となる。本論文では、トラス 構造を採用し、アクチュエータの配置を理論的に求める方 法を提案した。次いで、アクチュエータ力およびアクチュ
エータの制御長さを求める理論解析法を定式化し、その 結果を利用する制御方法を提示した。

参考文献

1) 尾田：機械槽造設計の最適化手法とその応用, 機械の研究、第 40 巻 6 号,1988

2) 梅谷: 骨の形態と生長変形法、日本機械学会誌、第 79 巻 693 号,pp.749-754.,1976

3) 中桐、野口、谷: 応力に基つく粫造形状の有限要素法シン セシス、構造工学における数值解析シンポシュウム、第 12 巻,pp.97-102.,1988

4) 瀬口、多田: 逆変分原理に上る構造物の形状决定問題、日 本機械学会論文集、第 44 巻 381 号,pp.1469-1477,1978

5) 中村、大崎：極率半径をサブパラメータとした振動数領域 に対する最適円筒状立体トラス生成法、槽造工学論文集、 35B,103-110,1989

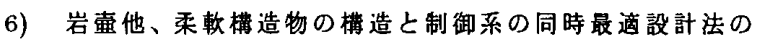
開発，日本機械学会論文集 (C 編), 57 巻, 534 号, pp.407-412,1991

7) 日本機械学会編：構造・材料の最道設計、技報堂出版、 1989.

8) 半谷、関:ホモロガス変形を制約条件とする立体 トラス棒造の形態解析、日本建策学会構造系論文報告集、 第 405,pp.97-102,第 405,pp.97-102,1989

9) 半谷、原田: 変位モード指定の槽造形態解析法、日本建築 学会橉造系論文報告集、第 453 号,pp.95-100,1993

10) Hoerner,S. : Homologous Deformations of Tiltable Telescopes, Joumal of the Structural Division, ASCE, No. ST5, 1967, pp.461-485.

11) 丹羽、吉川、中桐: 二次曲線保持のホモロジー設計、槽造 エ学における数值解析法シンポシュウム論文集、第 17 巻, pp.507-512,1993

12）半谷、川口: 形態解析、培風館、1991

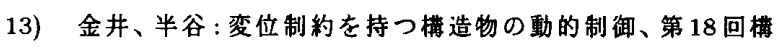
造工学におりる数值解析法シンポシュウム,pp.383-388,1994 